\title{
Incidence of Yersinia enterocolitica in raw farm and market milk sample
}

\author{
Aisha Saad Shoeib, Marwa Ibrahim El -Toukhy, Mohammed El-Sherbini El-Sayed
}

Department of Food Hygiene and Control, Faculty of Veterinary Medicine, Mansoura University, Egypt.

\section{ARTICLE HISTORY}

Received: 28.03.2021

Revised: 03.04.2021

Accepted: 03.11.2021

Corresponding author: Marwa Ibrahim EI Toukhy; Tel: +201005409902

Email: drmarwatokhy@mans.edu.eg;

Orcid https://orcid.org/0000-0002-6620-5629

\section{ABSTRACT}

\begin{abstract}
Objectives: This study was applied to investigate the incidence of Yersinia enterocolitica in raw farm and market milk and studying the quality drawbacks which might happen in milk as a result of its existence. Design: Observation study.

Samples: One hundred raw milk samples.

Procedures: Fifty bulk tank milk (BTM), 25 individual milk \& 25 market milk samples were collected from various dairy farms and supermarkets in Dakahlia Governorate, Egypt. The quality assessment of the samples began with evaluating the milk physical characteristics including color, odor, $\mathrm{pH}$ and the titratable acidity that reflected the hygienic quality of milk production on farm levels. Then the samples were directed for biochemical and microbiological examination with subsequent PCR approach.

Results: The range of titratable acidity started from $0.11-0.20 \%$ lactic acid with a mean value of $0.15 \pm$ 0.004. While for microbiological examination of the samples by using the conventional methods of cultivation on (CIN) agar medium, 33 presumptive Yersinia isolates were recovered and intended for biochemical tests among which 5 out of these latter isolates were confirmed as $Y$. enterocolitica by applying $\mathrm{PCR}$, through detecting the presence of 16srRNA gene. Also, this study evaluates not only the public health of consumers concerning the titratable acidity of the examined samples, but also the economic importance of these retailed samples in supermarkets; as $Y$. enterocolitica could be transmitted through the consumption of raw milk.

Conclusion and Clinical Relevance: The $Y$. enterocolitica incidence was $29 \%$ in the examined raw farm and
\end{abstract} market milk samples.

.Keywords: bulk tank milk, CIN, Cefsulodin, Irgasan, Novobiocin

\section{INTRODUCTION}

Milk is considered a good medium for microbial growth [1]. which plays an important role in food borne pathogen transmission. Yersinia is one of these enteric microorganisms which is a Gram-negative bacillus to coccobacillus bacterium that could be found in different environmental and food sources $[2,3]$. This pathogen could be transmitted through the consumption of contaminated milk or pork [2]. Moreover, some virulent strains have been also detected in milk and dairy products $[4,5] . Y$. enterocolitica is the most important pathogenic member of its genus [6, 7]. Several outbreaks have been listed due to the ingestion of contaminated milk with $Y$. enterocolitica [8]. Y. enterocolitica has been the third most commonly zoonotic disease following Campylobacter and Salmonella species [9]. It causes yersiniosis in human and animal. The yersiniosis is self-limiting disease with intestinal and extraintestinal sings. The intestinal sings ranged from gastroenteritis to acute enteritis, abdominal pain, mesenteric lymphadenitis and pseudo appendicitis which is confused from acute appendicitis mainly in children or septicemia in

hygiene in correlation to the incidence of Yersinia enterocolitica as well as the detection of 16srRNA gene using PCR method.

\section{MATERIAL AND METHODS}

1.1. Samples immune-comprised people [10]. While the reactive arthritis and erythema nodosum appeared as extra intestinal and post infection sequelae [11].

This microorganism is classified into six biotypes (1A, 1B, $2,3,4$ and 5), $1 A$ considered non-virulent , while the others can cause diseases, of which more than 70 serotypes are found according to their $\mathrm{O}$ lipopolysaccharide determinants $\mathrm{O}: 3,0: 8,0: 9$ and $0: 5,27[12,13]$.

Also, being a psychrotrophic organism, it can grow at the temperature of $4^{\circ} \mathrm{C}$. Consequently, causing the spoilage of stored refrigerated milk that is intended for consumption or manufacture which considered both a public health risk and economic loss; as it has the ability to release heat resistant enzymes (lipase \& protease) that can resist heat treatment and maintain itself in milk affecting negatively on milk quality [14]. Therefore, this study was undertaken to evaluate the quality of farm and market raw milk by measuring its titratable acidity that is an important parameter for food

One hundred milk samples [50 bulk tank milk (BTM), 25 individual milk and 25 market milk] were collected from various dairy farms and supermarkets in Dakahlia Governorate, Egypt. About $250 \mathrm{ml}$ of raw milk samples were collected in clean, dry, sterile bottles that placed in an insulated ice box and transferred immediately to the laboratory to be examined [15]. 


\subsection{Chemical examination of samples}

All raw milk samples were examined whether they heat treated or not by applying Storch test [16]. Then, the titratable acidity of raw milk samples were determined by using the standard method [17].

\subsection{Isolation and identification of Y. enterocolitica: [18].}

For enrichment, $25 \mathrm{ml}$ of each milk sample were added to $225 \mathrm{ml}$ of peptone sorbitol bile salt broth (PSB) at pH 7.2 followed by the incubation at $25^{\circ} \mathrm{C}$ for $3-4$ days with shaking every day. For the alkali treatment, $0.5 \mathrm{ml}$ of the enriched PSB broth was transferred to $4.5 \mathrm{ml}$ of $0.5 \%$ potassium hydroxide (KOH) solution and mixed for 20 seconds [19]. ; in order to decrease back-ground microflora and to give chance for Yersinia to grow well [2]. $0.1 \mathrm{ml}$ of the enrichment broth was streaked on CIN agar plate [20].with Yersinia selective supplement (SR0109). The cultured plates were incubated at $25-30^{\circ} \mathrm{C}$ for $24 \mathrm{hr}$. The suspected colonies appeared as small colonies with deep red center with sharp borders surrounded by clear colorless zone (bull's eye) appearance as shown in figure (1)[21]. Suspected colonies were transferred for microscopical examination then biochemical tests; catalase [22],Triple Sugar Iron [23], Christensen urea agar [24] and motility test [25] at two temperatures of incubation $\left(25^{\circ} \mathrm{C}\right.$ and $37^{\circ} \mathrm{C}$ for 48 hours). By using advanced techniques, 5 biochemically confirmed isolates were subjected to PCR to detect the 16srRNA using a primer sequence 5'-3' AAT ACC GCA TAA CGT CTT CG CTT CTT CTG CGA GTA ACG TC 330 bp [26]. master-mix [Emerald Amp GT PCR (Takara) - Code No. RR310A] and Gel Pilot 100 bp ladder (cat. no. 239035) supplied from QIAGEN (USA). as shown in figure (2).

\section{RESULTS}

The titratable acidity parameter is used as an indicator for the raw milk quality and this is achieved by the measurement of lactic acid content in the milk [27]. If the acid content was high, the titratable acidity would be increased. By applying the standard method of titratable acidity for raw milk samples, the percentage ranged from 0.11 to 0.20 with a mean value of $0.15 \pm 0.004$, where the highest percentage was found in market raw milk $(0.2 \%)$ followed by bulk tank raw milk $(0.19 \%)$ and finally the lowest percentage was found in individual animal raw milk (0.18\%) as shown in table (1).

Regarding $Y$. enterocolitica, the highest incidence of $Y$. enterocolitica was (32\%) in 16 bulk farm milk. But in individual farm raw milk samples, it was (24\%) and (28\%) in 7 market milk samples as shown in table (2).

There was non-significant correlation $(r=-\mathbf{0 . 2 3 9}, p=0.148)$ between the titratable acidity and the isolated $Y$. enterocolitica; the more the incidence the more tolerance against the produced acidity.

According to table (3), some competitor microorganisms were recovered upon the cultivation on CIN agar medium including non- lactose fermenter species as Pseudomonas beside lactose fermenter ones as Escherichia coli and
Klebsiella which contributed to the increase of milk acidity as a result of milk lactose fermentation.

Y. enterocolitica was found in 29 out of 100 examines samples, of which five of them were confirmed to have 16 srRNA gene.

Table 1: The titratable acidity in raw milk samples.

\begin{tabular}{lccccc} 
Samples & No. & Min. & Max. & Mean & SED. \\
& & & & & 0.0 \\
BTM & 50 & 0.12 & 0.19 & 0.15 & 04 \\
& & & & & \\
$\begin{array}{l}\text { Individual raw } \\
\text { milk }\end{array}$ & 25 & 0.11 & 0.18 & 0.14 & \pm 0.005 \\
Market raw milk & 25 & 0.13 & 0.20 & 0.15 & \pm 0.004 \\
\hline
\end{tabular}

Table 2. The incidence of $Y$. enterocolitica in the examined samples.

$\begin{array}{llll}\text { Samples } & \begin{array}{l}\text { No. of } \\ \text { samples }\end{array} & \begin{array}{l}\text { No. of } \\ \text { positive }\end{array} & \text { Percentage } \\ \text { BTM } & 50 & 16 & 32 \\ \text { Individual raw milk } & 25 & 6 & 24 \\ \text { Market raw milk } & 25 & 7 & 28 \\ \text { Tot Total } & 100 & 29 & 29\end{array}$

Table 3. Incidence of some competitors in the examined samples.

\begin{tabular}{|c|c|c|c|c|c|}
\hline & $\begin{array}{l}\text { No. of } \\
\text { samples }\end{array}$ & $\begin{array}{l}\text { No. of } \\
\text { isolates }\end{array}$ & $\begin{array}{l}\text { E. } \\
\text { coli }\end{array}$ & Klebsiella & Pseudomonas \\
\hline $\begin{array}{l}\text { BTM } \\
\text { Individua }\end{array}$ & 50 & 63 & 36 & 18 & 9 \\
\hline $\begin{array}{l}\text { I raw } \\
\text { milk }\end{array}$ & 25 & 26 & 16 & 7 & 3 \\
\hline $\begin{array}{l}\text { Market } \\
\text { raw milk }\end{array}$ & 25 & 28 & 11 & 12 & 5 \\
\hline
\end{tabular}

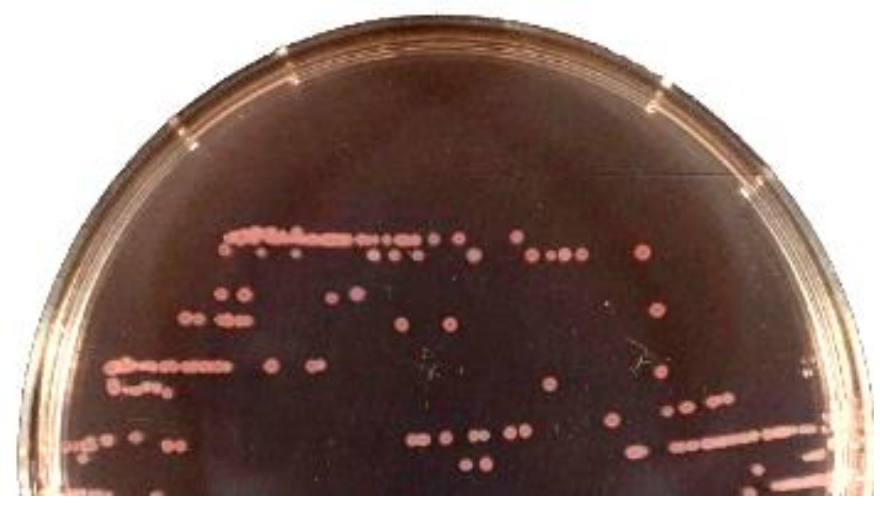

Figure 1. Colonies of $Y$. enterocolitica on (CIN) agar medium that appeared with deep red center and sharp borders surrounded by clear colorless zone (bull eye's appearance). 


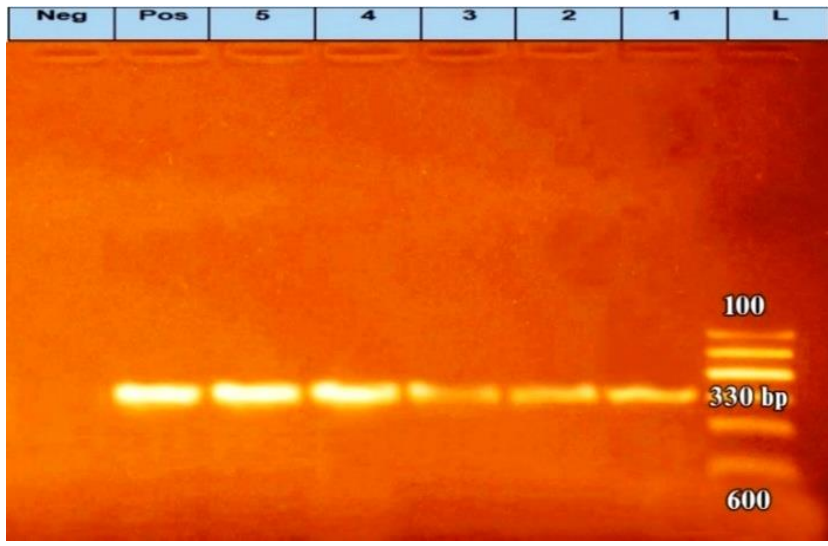

Figure 2. Agarose gel electrophoresis of PCR for 16sRrNA Y. enterocolitica (330) bp. Lane (L): 100 bp bladder as DNA marker; Lanes 1,2,3,4,5 positive for $Y$. enterocolitica; Lane pos: control $Y$. enterocolitica strain.

\section{DISSCUSION}

The titratable acidity in our study was slightly higher than that recorded by [27].. Similar results in (BTM) samples were reported by $[28,29]$, who found that the titratable acidity was 0.14 up to 0.16 and 0.17 to 0.19 , respectively. While in individual raw milk samples, Similar mean value $(0.14 \%)$ was obtained by $[30,31]$. Higher individual mean raw milk acidity was recorded by [32, 33]. (0.18 $\pm 0.01,0.19 \pm 0.006)$, respectively. But The lower value was reported by [34], who declared a level of 0.08 . On the other hand, the minimum titratable acidity value of market milk samples was 0.13 while the maximum value was 0.2 and the mean $0.15 \pm 0.004$. This result was nearly like that obtained by [35], who reported a titratable acidity ranged from 0.19 to 0.25 . While the higher titratable acidity value was recorded by $[36,37]$, who found that the mean value was $0.23 \pm 0.01$, and $0.19 \pm 0.023$, respectively. The slightly increased titratable acidity of market raw milk could be attributed to improper cooling in supermarkets or small dairy shops beside mixing milk of different qualities from various sources or farms together. Yet this increased acidity favors the existence and growth of Yersinia enterocolitica later.

The obtained incidence in this study was nearly similar results to that obtained by [38-40], who detected the presence of $Y$. enterocolitica in $26.6 \%, 30 \%, 25 \%$, of examined samples, respectively. But the lower result was recorded by [41], in a percentage of $7.1 \%$. While $[42,43]$. reported higher percentage $(65.5 \%, 63.3 \%$, respectively).

Enteric $Y$. enterocolitica tolerated the acidic $\mathrm{pH}$ (from 2 to 6 ) showing nearly $85 \%$ survival as obtained by [44]. Also, this pathogen could withstand and survive at high lactic acid concentration during fermentation process as illustrated by [45].

Milking process as well as milk handling procedures play an important role in the contamination of raw milk [46]. Many pathogens as E. coli, Salmonella, Pseudomonas, Klebsiella, Y. enterocolitica could contaminate milk [47] and subsequently affecting its quality.
The molecular methods are more specific, accurate for the identification of $Y$. enterocolitica than that based on biochemical and morphological characteristics. Five isolates were confirmed as $Y$. enterocolitica using gene targeting 16 srRNA which is used in a wide range for specificity of Yersinia species as reported by[29, 48, 49].

$Y$. enterocolitica has a public health importance due to its ability to grow in a wide range of temperature from - 4 to 30 ㄷ. So, it considered a member of psychrotrophic bacteria [42], resulting in the existence of risk conditions related to the consumption of contaminated milk. Furthermore, $Y$. enterocolitica has lipolytic and proteolytic activity enabling the release of extracellular alkaline metalloprotease enzyme [50], beside other extracellular heat stable protease enzymes secreted by these psychrotrophic microorganisms which lead to the break-down of milk proteins making changes in milk quality such as gelation of UHT milk, loss of the milk heatstability properties and development of off-flavor [51].

At the level of public health, $Y$. enterocolitica is one of the most important pathogenic bacteria that is implicated in outbreaks of food borne diseases including food poisoning; and 6766 human yersiniosis cases were detected in Europe only during the year of 2012 [9, 52]. The post infection of yersiniosis could result in endocarditis, pneumonia, pharyngitis, osteomyelitis and conjunctivitis as reported by [53].

\section{Conclusion}

In conclusion, is an important guidance for consumers to avoid the risks upon the consumption of raw milk that might carry this pathogen in order to decrease food borne diseases. Also, the importance of milk heat treatment before consumption.

\section{Acknowledgement: NA}

\section{Conflict of interest}

The authors declare that there is no conflict of interest in the current research work.

\section{Authors contribution}

All authors contributed equally to this work whereas they designed, conducted the work. All authors reviewed the manuscript. All authors read and approved the final manuscript.

\section{REFERENCES}

[1] Ledenbach LH, Marshall RT. Microbiological Spoilage of Dairy Products. Compendium of the Microbiological Spoilage of Foods and Beverages: Springer New York; 2009. p. 41-67. https://doi.org/10.1007/978-1-44190826-1_2

[2] Thoerner P, Bin Kingombe Cl, Bögli-Stuber K, Bissig-Choisat B, Wassenaar TM, Frey J, et al. PCR Detection of Virulence Genes in Yersinia enterocolitica and Yersinia pseudotuberculosis and Investigation of Virulence Gene Distribution. Applied and Environmental Microbiology. 2003;69:1810-6. https://doi.org/10.1128/AEM.69.3.1810-1816.2003

[3] Lambertz ST, Nilsson C, Hallanvuo S, Lindblad M. Real-time PCR method for detection of pathogenic Yersinia enterocolitica in food. Applied and 
Environmental

Microbiology

https://doi.org/10.1128/AEM.00405-08

[4] Soltan-Dallal M-M, Tabarraie A, MoezArdalan K. Comparison of four methods for isolation of Yersinia enterocolitica from raw and pasteurized milk from northern Iran. International Journal of Food Microbiology. 2004;94:87-91. https://doi.org/10.1016/j.ijfoodmicro.2003.10.017

[5] Hanifian S, Khani S. Prevalence of virulent Yersinia enterocolitica in bulk raw milk and retail cheese in northern-west of Iran. International Journal of Food Microbiology. 2012;155:89-92. https://doi.org/10.1016/j.ijfoodmicro.2012.01.012

[6] Bottone EJ. Yersinia enterocolitica: overview and epidemiologic correlates. Microbes and infection. 1999;1:323-33 https://doi.org/10.1016/S1286-4579(99)80028-8

[7] Bursová Š, Necidová L, Haruštiaková D, Janštová B. Growth potential of Yersinia enterocolitica in pasteurised cow's and goat's milk stored at $8^{\circ}$ C and $24^{\circ}$ C. Food Control. 2017;73:1415-9. https://doi.org/10.1016/j.foodcont.2016.11.006

[8] Ackers ML, Schoenfeld S, Markman J, Smith MG, Nicholson Mabel A, DeWitt W, et al. An Outbreak ofYersinia enterocoliticaO:8 Infections Associated with Pasteurized Milk. The Journal of Infectious Diseases. 2000;181:1834-7. https://doi.org/10.1086/315436

[9] EFSA. The European Union summary report on trends and sources of zoonoses, zoonotic agents and food-borne outbreaks. . Article. 2012;13:4329.

[10] Petsios S, Fredriksson-Ahomaa M, Sakkas H, Papadopoulou C. Conventional and molecular methods used in the detection and subtyping of Yersinia enterocolitica in food. International Journal of Food Microbiology. https://doi.org/10.1016/j.ijfoodmicro.2016.08.015

[11] Elisa, Huovinen, Sihvonen LM, Virtanen MJ, Haukka K, Siitonen A, et al. Symptoms and sources of Yersinia enterocolitica-infection: a casecontrol study. BMC infectious diseases. 2010;10:1-9. https://doi.org/10.1186/1471-2334-10-122

[12] Peruzy MF, Murru N, Perugini AG, Capuano F, Delibato E, Mercogliano $\mathrm{R}$, et al. Evaluation of virulence genes in Yersinia enterocolitica strains using SYBR Green real-time PCR. Food microbiology. 2017;65:231-5. https://doi.org/10.1016/j.fm.2017.03.004

[13] Saraka D, Savin C, Kouassi S, Cissé B, Koffi E, Cabanel N, et al. Yersinia enterocolitica, a neglected cause of human enteric infections in Cote d'Ivoire. PLoS neglected tropical diseases. 2017;11:e0005216. https://doi.org/10.1371/journal.pntd.0005216

[14] Baglinière F, Jardin J, Gaucheron $F$, de Carvalho AF, Vanetti MCD. Proteolysis of casein micelles by heat-stable protease secreted by Serratia liquefaciens leads to the destabilisation of UHT milk during its storage. International Dairy Journal. 2017;68:38-45. https://doi.org/10.1016/j.idairyj.2016.12.012

[15] APHA "American Public Health Association". Standard Methods for Examination of Dairy product . 17th ed ., wehr ,H.M. and Frank ,J.F. (Eds), Washington, Dc. 2001-3710. 2004.

[16] Lampert LM. Modern dairy products 3rd edition. Chem. Publ. Co., Inc. New York. 1975:227-9.

[17] AOAC. Official methods of analysis .12th ed. Association of official Analytical Chemist (AOAC International): Washington DC. 1990.

[18] ISO 10273. Microbiology of food and animal feeding stuffs - Horizontal method for the detection of presumptive pathogenic Yersinia enterocolitica: ISO. https://wwwisoorg/standard/34564html Accessed 22 Feb 2017. 2003.

[19] Aulisio CC, Mehlman IJ, Sanders AC. Alkali method for rapid recovery of Yersinia enterocolitica and Yersinia pseudotuberculosis from foods. Applied and Environmental Microbiology. 1980;39:135-40. https://doi.org/10.1128/aem.39.1.135-140.1980

[20] Oxoid. The Oxoid Manual of Culture Media Ingredients and other Laboratories Services" (5th ed.), Oxoid Limited, Hampshire, England. 1982.

[21] Weagant S, Feng P. Yersinia. Pages 421-428 in Compendium of Methods for the Microbiological Examination of Foods, 3th ed. F. Pouch Downes and K. Ito, ed. American Public Health Association, Washington DC. 2001 https://doi.org/10.2105/9780875531755ch41

[22] Leskinen K, Varjosalo M, Skurnik M. Absence of YbeY RNase compromises the growth and enhances the virulence plasmid gene expression of Yersinia enterocolitica 0:3. Microbiology. 2015;161:28599. https://doi.org/10.1099/mic.0.083097-0
[23] Fukushima H, Shimizu S, Inatsu Y. Yersinia enterocoliticaandYersinia pseudotuberculosisDetection in Foods. Journal of Pathogens. 2011;2011:1-9. https://doi.org/10.4061/2011/735308

[24] Xanthopoulos V, Tzanetakis N, Litopoulou-Tzanetaki E. Occurrence and characterization of Aeromonas hydrophila and Yersinia enterocolitica in minimally processed fresh vegetable salads. Food Control. 2010;21:3938. https://doi.org/10.1016/j.foodcont.2009.06.021

[25] Gupta V, Gulati P, Bhagat N, Dhar MS, Virdi JS. Detection of Yersinia enterocolitica in food: an overview. European Journal of Clinical Microbiology \& Infectious Diseases. 2015;34:641-50. https://doi.org/10.1007/s10096-014-2276-7

[26] Wannet WJB, Reessink M, Brunings HA, Maas HME. Detection of Pathogenic Yersinia enterocolitica by a Rapid and Sensitive Duplex PCR Assay. Journal of Clinical Microbiology. 2001;39:4483-6. https://doi.org/10.1128/JCM.39.12.4483-4486.2001

[27] FAO, ) FaAO. Training Programme for Small Scale Dairy Traning Institute. In : Milk Processing Guide Series 2: Milk Testing and Quality Control ,. FAO\TCP\KEN 6611 Project, Naivasha 2013.

[28] Ismail MM, Ammar EMA, El-Shazly AA, Eid MZ. Impact of cold storage and blending different lactations of cows milk on the quality of Domiati cheese. African Journal of Food Science. 2010;4:503-13.

[29] Özdemir F, Arslan S. Genotypic and phenotypic virulence characteristics and antimicrobial resistance ofYersiniaspp. isolated from meat and milk products. Journal of Food Science. 2015;80:M1306-M13. https://doi.org/10.1111/1750-3841.12911

[30] Hossain MB, Dev SR. Physiochemical characteristics of various raw milk samples in a selected dairy plant of Bangladesh. International Journal of Engineering. 2013;1:2305-8269.

[31] Elhasan SM, Bushara AM, Abdelhakam KE, Elfaki HA, Eibaid Al, Farahat $\mathrm{FH}$, et al. Effect of heat treatments on physico-chemical properties of milk samples. Journal of Academia and Industrial Research (JAIR). 2017;6:2278-5213.

[32] Meshref AMS. Bacteriological quality and safety of raw cow's milk and fresh cream. Slovenian Veterinary Research. 2013;50:21-30.

[33] Gemechu T, Beyene F, Eshetu M. Physical and chemical quality of raw cows milk produced and marketed in Shashemene Town, Southern Ethiopia. ISABB Journal of Food and Agricultural Sciences. 2015;5:7-13.

[34] Moustafa HM. Occurrence and significance of enterococci in milk and some dairy products .M. V. Sc. Fac. Vet. Med., Zagazig. Univ. 1988.

[35] Zerihun, Asefa, Teshome G. Physical Properties and Chemical Compositions of Raw Cow Milk in Milk Shades Around Addis Ababa, Ethiopia. 2019.

[36] Salman AMA, Elnasri HA. Somatic cell count, total bacterial count and acidity properties of milk in Khartoum State, Sudan. Journal of Cell and Animal Biology. 2011;5:223-30.

[37] Gemechu T, Amene T. Physicochemical properties and microbial quality of raw cow milk produced by smallholders in Bench Maji-Zone, Southwestern Ethiopia. Food Science and Quality Management. 2016;54:47-54.

[38] Ibrahim A, Rae ICM. Isolation of Yersinia enterocolitica and Related Species from Red Meat and Milk. Journal of Food Science. 1991;56:15246. https://doi.org/10.1111/j.1365-2621.1991.tb08631.x

[39] Hamama A, El Marrakchi A, El Othmani F. Occurrence of Yersinia enterocolitica in milk and dairy products in Morocco. International Journal of Food Microbiology. 1992;16:69-77. https://doi.org/10.1016/0168-1605(92)90127-0

[40] Grant MA, Eklund CA, Shields SC. Monitoring Dairy Silage for Five Bacterial Groups with Potential for Human Pathogenesis. Journal of Food Protection. 1995;58:879-83. https://doi.org/10.4315/0362-028X58.8.879

[41] Ye YW, Ling N, Han YJ, Wu QP. Detection and prevalence of pathogenic Yersinia enterocolitica in refrigerated and frozen dairy products by duplex PCR and dot hybridization targeting the virF and ail genes. Journal of Dairy Science. 2014;97:6785-91. https://doi.org/10.3168/jds.20148382

[42] Jamali H, Paydar M, Radmehr B, Ismail S. Prevalence, characterization, and antimicrobial resistance of Yersinia species and Yersinia enterocolitica isolated from raw milk in farm bulk tanks. Journal of Dairy Science. 2015;98:798-803. https://doi.org/10.3168/jds.2014-8853

[43] Seshadhri SP, Thangavelu T, Thangavel SM. Genetic diversity among Yersinia enterocolitica isolated from sewage, raw milk and packed foods. 
Journal of Microbiology, Biotechnology and Food Sciences. 2015;04:2716. https://doi.org/10.15414/jmbfs.2014-15.4.3.271-276

[44] Tania F, De Koning-Ward, Robins-Browne RM. Contribution of urease to acid tolerance in Yersinia enterocolitica. Infection and immunity. 1995;63:3790-5. https://doi.org/10.1128/iai.63.10.3790-3795.1995

[45] Gulmez M, Guven A. Note: Behaviour of Escherichia Coli O157: H7, Listeria Monocytogenes $4 \mathrm{~b}$ and Yersinia Enterocolitica $\mathrm{O} 3$ in Pasteurised and Non-pasteurised Kefir Fermented for One or Two Days. Food Science and Technology International. 2003;9:365-9. https://doi.org/10.1177/1082013203039252

[46] Bille PG, Haradoeb BR, Shigwedha N. Evaluation of chemical and bacteriological quality of raw milk from Neudamm dairy farm in Namibia. African Journal of Food, Agriculture, Nutrition and Development. 2010;9. https://doi.org/10.4314/ajfand.v9i7.47682

[47] Marco ML, Wells-Bennik MHJ. Impact of bacterial genomics on determining quality and safety in the dairy production chain. International Dairy Journal. 2008;18:486-95. https://doi.org/10.1016/j.idairyj.2007.11.017

[48] Ahmed HA, Tahoun ABMB, Abou Elez RMM, Abd El-Hamid MI, Abd Ellatif SS. Prevalence of Yersinia enterocolitica in milk and dairy products and the effects of storage temperatures on survival and virulence gene expression. International Dairy Journal. 2019;94:16-21. https://doi.org/10.1016/j.idairyj.2019.02.010

[49] Khalid DM, Abbas BA. Prevalence, antibiotic susceptibility, and virulence factors of Yersinia enterocolitica isolated from raw milk in Basrah, Iraq. Bulgarian Journal of Veterinary Medicine. 2021;24. https://doi.org/10.15547/bjvm.2019-0044

[50] Ribeiro Júnior JC, de Oliveira AM, Silva FdG, Tamanini R, de Oliveira ALM, Beloti $V$. The main spoilage-related psychrotrophic bacteria in refrigerated raw milk. Journal of Dairy Science. 2018;101:75-83. https://doi.org/10.3168/jds.2017-13069

[51] Caldera L, Franzetti L, Van Coillie E, De Vos P, Stragier P, De Block J, et al. Identification, enzymatic spoilage characterization and proteolytic activity quantification of Pseudomonas spp. isolated from different foods. Food Microbiology. 2016;54:142-53. https://doi.org/10.1016/j.fm.2015.10.004

[52] European Food Safety Authority. European Centre for Disease Prevention and Control. (2012): The European Union summary report on trends and sources of zoonoses,. zoonotic agents and food-borne outbreaks. 2010.

[53] Bonardi S, Bruini I, D'Incau M, Van Damme I, Carniel E, Brémont S, et al. Detection, seroprevalence and antimicrobial resistance of Yersinia enterocolitica and Yersinia pseudotuberculosis in pig tonsils in Northern Italy. International journal of food microbiology. 2016;235:125-32. https://doi.org/10.1016/j.ijfoodmicro.2016.07.033 